\title{
PENGEMBANGAN LKPD BERBASIS PENDEKATAN DISCOVERY LEARNING PADA PEMBELAJARAN TEMATIK TERPADU KELAS V SEKOLAH DASAR
}

\author{
Shella Marcelina ${ }^{1}$, Silfi Melindawati ${ }^{2}$ \\ 1,2.STKIP Adzkia, Indonesia.
}

Email: $\underline{\text { shella.m@ @stkipadzkia.ac.id }}^{1}, \underline{\text { silfi.m@ @stkipadzkia.ac.id }}^{2}$

\begin{abstract}
This research is motivated by observations, that the LKPD used is still insufficient in inviting active students in the learning process, as well as developing social, emotional, moral and aesthetic communication in children. The problems studied are: 1. How is the development of Student Worksheet (LKPD) based on the Discovery Learning Approach in Integrated Thematic Learning Theme 9 Sub-theme 1 Class V SD Negeri 12 Pisang Padang City; 2. What is the validity, effectiveness, and practicality of Student Worksheet (LKPD) Based on the Discovery Learning Approach in Integrated Thematic Learning Theme 9 Sub-theme 1 Class V SD Negeri 12 Pisang Kota Padang?. This research and development resulted in LKPD products based on discovery learning approaches on the theme of 9 sub-themes 1 and obtained valid / feasible and practical product results for use, the LKPD products developed had fulfilled the components as good teaching materials for use in the learning process because they were in accordance with KI, KD and the suitability of attractive colors, images, sizes and fonts. In addition, according to students' circumstances, the language used is easy to understand, has learning instructions and an assignment assessment score. The form of the assignment is simple but able to cover all learning indicators. From the results of the assessment of the overall average score on the LKPD validation is 84.3 including in the very valid category, it can be used without revision. This shows that the developed LKPD is valid. Thus, it means that the developed LKPD is good and can be used as a learning resource for students in the development of LKPD based on the discovery learning approach in integrated thematic learning in class $V$ elementary schools. The level of practicality of the product is seen from the results of the responses of 1 class teacher, 5 students and their parents with an average score of 95\% (Very Interested), which means that the LKPD products developed are practical for use.
\end{abstract}

Keywords: LKPD, Discovery Learning

\begin{abstract}
ABSTRAK
Penelitian ini dilatarbelakangi oleh observasi, bahwa LKPD yang digunakan masih kurang dalam mengundang siswa aktif dalam proses pembelajaran, serta mengembangkan komunikasi sosial, emosional, moral dan estetik pada anak. Permasalahan yang dikaji adalah: 1. Bagaimana pengembangan Lembar Kerja Siswa (LKPD) Berbasis Pendekatan Discovery Learning pada Pembelajaran Tematik Terpadu Tema 9 Sub Tema 1 Kelas V SD Negeri 12 Pisang Kota Padang; 2. Bagaimana validitas, keefektifan, dan kepraktisan Lembar Kerja Siswa (LKPD) Berdasarkan Pendekatan Discovery Learning pada Pembelajaran Tematik Terpadu Tema 9 Sub Tema 1 Kelas V SD Negeri 12 Pisang Kota Padang ?. Penelitian dan pengembangan ini menghasilkan produk LKPD berbasis pendekatan discovery learning pada tema 9 sub tema 1 dan diperoleh hasil produk yang valid / layak dan praktis untuk digunakan, produk LKPD yang dikembangkan telah memenuhi komponen sebagai bahan ajar yang baik untuk digunakan dalam pembelajaran. proses pembelajaran karena telah sesuai dengan KI, KD dan kesesuaian warna, gambar, ukuran dan font yang menarik. Selain itu, sesuai dengan keadaan siswa, bahasa yang digunakan mudah dipahami, memiliki petunjuk pembelajaran dan skor penilaian tugas. Bentuk tugasnya sederhana namun mampu mencakup semua indikator pembelajaran. Dari hasil penilaian skor rata-rata keseluruhan pada validasi LKPD adalah 84,3 termasuk dalam kategori sangat valid dapat digunakan tanpa revisi. Hal ini menunjukkan LKPD yang dikembangkan valid. Artinya, LKPD yang dikembangkan sudah baik dan dapat digunakan sebagai sumber belajar bagi siswa dalam pengembangan LKPD berbasis pendekatan discovery learning dalam pembelajaran tematik terintegrasi di kelas V SD. Tingkat kepraktisan produk dilihat dari hasil tanggapan 1 guru kelas, 5 siswa dan orang tua siswa dengan skor rata-rata 95\% (Sangat Tertarik) yang berarti produk LKPD yang dikembangkan praktis untuk digunakan.
\end{abstract}

Kata Kunci: LKPD, Discovery Learning. 


\section{PENDAHULUAN}

Kurikulum 2013 mengandung lima esensi, yaitu pembelajaran tematik, pembelajaran kontekstual, pendidikan karakter, pendekatan saintifik, dan penilaian autentik. Berkaitan dengan salah satu esensi pada kurikulum 2013 yaitu pendekatan saintifik, terdapat aktivitas sains yang perlu dikuasai siswa, yaitu mengamati, menanya, menalar, mencoba, dan membentuk jejaring Permendikbud 2013). Mengacu pada kurikulum 2013 tersebut, maka penulis tertarik untuk melakukan sebuah penelitian yang berkaitan dengan pengembangan Lembar Kerja Peserta Didik (LKPD) yang didalamnya berisi rangkaian kegiatan dan tugas-tugas yang harus dilakukan siswa dengan tujuan untuk meningkatkan aktivitas sains siswa berdasarkan pendekatan discovery learning sehingga dapat mencapai kompetensi yang diharapkan.

\section{METODE PENELITIAN}

Jenis penelitian yang digunakan merupakanpenelitian danpengembangan atau yang biasa lebih dikenal sebagai penelitian R\&D (Research and Development).Penelitian dan pengembangan atau Research and Development (R\&D)adalah suatu proses atau langkah-langkah untuk mengembangkan suatu produk baruatau menyempurnakan produk yang telah ada yang dapat dipertanggungjawabkan. Sugiyono (2016:407) berpendapat bahwa metode penelitian dan pengembangan adalah metode penelitian yang digunakan untuk menghasilkan produk tertentu dan menguji keefektifan produk tersebut, sehingga dapat dikatakan bahwa penelitian dan pengembangan adalah metode penelitian untuk mengembangkan suatu produk sehingga menghasilkan produk baru sesuai dengan kebutuhan.

Desain penelitian ini menggunakan model pengembangan 4D (four-D). Model penelitian dan pengembangan model 4D terdiri dari 4 tahapan, yaitu; define,design, develop, dan disseminate (Thiagarajan, 1974) dalam Trianto (2019:93). Model pengembangan 4D dapat diadaptasi menjadi 4P, yaitu; pendefinisian, perancangan, pengembangan, dan penyebaran.

Teknik analisis data yang digunakan adalah analisis data deskriptif, yaitumendekripsikan gambaran LKPD tematik terpadu yang digunakan pendidik SD selama ini, tingkat validitas LKPD, kepraktisan LKPD, dan efektifitas LKPD yang digunakan.

Keterangan :

$$
\mathrm{R}=\frac{\sum_{i=1}^{n} v i j}{n m} \times 100 \%
$$

$\mathrm{R}$ : Rerata hasil penilaian dari para ahli/praktisi

Vij : Skor hasil penilaian para ahli/praktisi ke-j terhadap kriteria

n : Banyaknya para ahli/praktisi yang menilai

$\mathrm{m}$ : Banyaknya kriteria

Kategori validitas bahan ajar berdasarkan nilai akhir yang didapatkan dapat dilihat dari tabel berikut:

Tabel 1. Penskoran Validasi LKPD

\begin{tabular}{cc}
\hline Interval & Kategori \\
\hline $1,00-199$ & Tidak valid \\
\hline $2.00-2,99$ & Cukup valid \\
\hline $3,00-3.49$ & Valid \\
\hline $3.50-4,00$ & Sangat Valid
\end{tabular}

Sumber : (Widjajanti, 2008:58)

Analisis Data Uji Praktikalitas LKPD Tematik Terpadu 
Kategori praktikalitas LKPD berdasarkan nilai akhir yang diperoleh dapat dilihat pada tabel berikut:

Tabel 2. Kategori Kepraktisan LKPD

\begin{tabular}{cc}
\hline Interval & Kategori \\
\hline $55-59$ & Kurang Praktis \\
\hline $60-74$ & Cukup Praktis \\
\hline $75-84$ & Praktis \\
\hline $85-100$ & Sangat Praktis \\
\hline
\end{tabular}

Sumber : (Purwanto, 2006: 103)

a. Analisa Angket Respons Guru dan Peserta Didik

Pengisian angket dilakukan dengan menggunakan alternative jawaban berikut:

$1=$ Sangat tidak setuju

2 = Tidak Setuju

$3=$ Setuju

4 = Sangat Setuju

Perhitungan nilai akhir data angket dianalisis dengan menggunakan rumus dan Riduwan dan Sunarto (2007:23) yaitu sebagai berikut:

Keterangan:

NA $=$ Nilai Akhir

PS - Perolehan Skor

$\mathrm{SM}=$ Skor Maksimal

b. Analisa Lembar Observasi Penggunaan LKPD

Lembar observasi penggunaan LKPD berisi tentang deskripsi mengenai penggunaan LKPD oleh peserta didik yang ditinjau dari beberapa aspek penilaian. Data yang diperoleh disajikan dengan teknik deskriptif.

c. Analisis Efektivitas LKPD

Analisis efektivitas model pembelajaran discovery learning dilakukan berdasarkan data yang diperoleh dari instrumen pengumpulan data. Analisa data ini meliputi :

1. Analisa Data Penilaian Aktivitas Peserta didik

Data hasil pengisian levbar observasi aktivitas peserta didik dianalisis dengan perhitungan menggunakan rumus dari Arikunto (2006 : 233) yaitu:

Persentase $=\underline{\text { Persentase Frekuensi aktivitas peserta didik yang dilakukan }} \times 100 \%$

Jumlah peserta didik

Berdasarkan persentase yang diperoleh, dilakukan pengelompokan sesuai dengaan kriteria berikut:

Tabel 3. Kategori Penetapan Aktivitas Peserta didik

\begin{tabular}{cc}
\hline Interval & Kategori \\
\hline $81-100$ & Sangat Tinggi \\
\hline $61-80$ & Tinggi \\
\hline $41-60$ & Sedang \\
\hline $21-40$ & Rendah \\
\hline
\end{tabular}

Sumber : (Arikunto, 2006: 166)

2. Analisa Data Hasil Belajar Peserta Didik

Data penilaian hasil belajar peserta didik dikumpulkan berdasarkan penilaian pross dan hasil. Analisa data untuk penilaian proses belajar dengan penggunaan LKPD dapat dilakukan dengan langkah-langkah berikut:

1. Pemberian skor berdasarkan indikator pelaksanaan pembelajaran menggunakan

LKPD tematik terpadu yang dikembangkan 
2. Menjumlahkan skor dari masing-masing aspek yang dinilai.

3. Penentuan nilai dengan menggunakan rumus dari Abidin (2012:278) sebagai berikut:

$\mathrm{N}=\underline{\text { Skor yang diperoleh (SD) }} \times 100 \%$

Skor Ideal (SD)

Sedangkan untuk data penilaian hasil belajar peserta didik diperoleh dari hasil tes soal-soal evaluasi. Analisa data yang dilakukan dengan menggunakan perhitungan persentase peserta didik yang memenuhi kriteria ketuntasan minimal (KKM). Untuk pengembangan LKPD tematik terpadu menggunakan pembelajaran discovery learning dikatakan efektif, jika lebih dari $75 \%$ peserta didik mendapat nilai 80 KKM pembelajaran berdasarkan KKM SD tempat dilakukan uji coba.

\section{HASIL PENELITIAN DAN PEMBAHASAN}

Berdasarkan tahap-tahap pengembangan 4-D Models yang sudah dikemukakan pada bab 3, maka deskripsi hasil penelitian dibagi menjadi 4 bagian yaitu: tahap pendefinisian, tahap perancangan, tahap pengembangan, dan tahap penyebaran. Adapun deskripsi data hasil penelitian dijelaskan sebagai berikut:

\section{Hasil Tahap Pendefenisian (Define)}

Tahap pendefinisian adalah tahap untuk menetapkan dan mendefenisikan syaratsyarat pengembangan seperti menetapkan dan menganalisis kebutuhan di dalam proses pembelajaran. Adapun analisis tahap pendefenisian pada penelitian ini meliputi: analisis awal, analisis siswa (peserta didik), analisis kurikulum didalamnya membahasa analisis tugas, analisis konsep dan analisis perumusan tujuan pembelajaran. Analisis tersebut dipaparkan sebagai berikut:

\section{a. Analisis Awal}

Analisis awal merupakan menganalisis masalah yang diperlukan dalam proses pengembangan LKPD. Analisis awal dapat dikatakan juga sebagai analisis kebutuhan. Adapun analisis kebutuhan yang dilakukan pada penelitian ini adalah analisis pada beberapa LKPD yang digunakan pendidik dan peserta didik dalam proses pembelajaran. Melalui analisis beberapa buku, perlu dikembangkan LKPD. Dimana berdasarkan hasil analisis yang dilakukan, selama ini guru hanya memberikan arahan untuk mengerjakan LKPD yang berada pada buku siswa tanpa membuat LKPD baru untuk menarik motivasi siswa dalam belajar.

Dengan demikian, dapat dikatakan bahwa LKPD yang digunakan dalam pembelajaran belum dikembangkan secara efektif dan perlu revisi serta pengembangan lebih lanjut. Sajian materi pada LKPD perlu diberikan panduan berbagai tugas terkait memaksimalkan pemahaman peserta didik terhadap materi dan pertanyaan. Kemudian tampilan LKPD perlu didesain dengan cara yang berbeda agar lebih menarik sehingga peserta didik lebih termotivasi dalam mengerjakan LKPD. Berdasarkan analisis awal (analisis kebutuhan) yang dilakukan, maka dilakukan pengembangan LKPD berbasis pendekatan discovery learning pada pembelajaran tematik terpadu untuk membantu pendidik dalam membimbing dan memfasilitasi peserta didik untuk lebih aktif dan terampil dalam mengerjakan LKPD tematik terpadu.

\section{b. Analisis Siswa (Peserta didik)}

Analisis siswa (peserta didik) dilakukan untuk mengetahui kemampuan umum peserta didik dalam mengerjakan LKPD. Analisis ini dilakukan sebagai acuan dalam mengembangkan alat/tes dalam pengembangan LKPD. Peserta didik yang menjadi subjek penelitian adalah peserta didik kelas V SD. LKPD yang ada adalah hanya LKPD yang bersumber dari buku siswa kelas V SD sesuai dengan tema pembelajaran.

Namun LKPD tersebut membuat pembelajaran aktif tematik terpadu kurang bisa digunakan dengan efektif disebabkan adanya siswa yang tidak mengerti cara untuk 
mengisi LKPD tersebut. Selanjutnya diperlukan LKPD yang dapat mengembangkan keterampilan peserta didik dalam mengerjakan LKPD, sehingga keaktifan peserta didik benar-benar tergali dengan baik. LKPD yang digunakan hendaklah disesuaikan dengan karakteristik peserta didik.

\section{c. Analisis Kurikulum}

Dalam analisis kurikulum dijelaskan berupa analisis tugas, analisis konsep dan anlisis perumusan tujuan pembelajaran. Dimana tugas yang akan diberikan kepada siswa (peserta didik) dapat terlihat pada KI, KD dan tujuan pembelajaran yang disampaikan. Selanjutnya untuk analisis konsep adalah pengidentifikasian konsepkonsep yang akan disampaikan dalam pembelajaran serta penyusunan secara sistematis LKPD yang akan dikembangkan berdasarkan KI, KD dan tujuan pembelajaran.

dalam setiap RPP.

\section{Hasil Tahap Perancangan (Design)}

Berdasarkan analisis pada tahap pendefenisian maka dilakukan perancangan terhadap RPP dan LKPD berbasis pendekatan discovery learning pada pembelajaran tematik terpadu kelas V sekolah dasar.

\section{Hasil Tahap Pengembangan (Develop)}

Tahap pengembangan (develop) bertujuan menghasilkan LKPD berbasis pendekatan discovery learning pada pembelajaran tematik terpadu yang valid, praktis, dan efektif yang layak digunakan dalam proses pembelajaran. Tahap pengembangan meliputi validasi RPP dan LKPD, uji praktikalitas, dan uji efektivitas. Uji validitas dilakukan dengan memvalidasi RPP dan LKPD oleh para pakar dan praktisi. Uji praktikalitas dan efektivitas dilakukan pada saat uji coba produk yaitu dengan mengujicobakan LKPD yang telah dikembangkan dalam proses pembelajaran di kelas

Berdasarkan uraian di atas, secara keseluruhan hasil validasi RPP dan materi, validasi LKPD berupa validasi desain serta hasil validasi bahasa dan dapat dilihat pada Tabel berikut.

Tabel 4. Hasil Validasi Akhir Secara Keseluruhan

\begin{tabular}{llcl}
\hline NO & Aspek yang Dinilai & $\begin{array}{c}\text { Nilai } \\
\text { Validasi }\end{array}$ & \multicolumn{1}{c}{ Kategori } \\
\hline 1. & RPP & 85 & $\begin{array}{l}\text { Sangat Valid, tidak perlu } \\
\text { revisi }\end{array}$ \\
\hline 2. & Materi & 84 & $\begin{array}{l}\text { Sangat Valid, dapat digunakan } \\
\text { tanpa revisi }\end{array}$ \\
\hline 3. & Desain & 85 & Valid dengan revisi \\
\hline 4. & Bahasa & 83 & Valid dengan revisi \\
\hline & Rata-rata & $\mathbf{8 4 , 3}$ & Sangat Valid \\
\hline
\end{tabular}

Berdasarkan Tabel di atas terlihat nilai validasi untuk aspek RPP, validasi materi, validasi desain, dan validasi bahasa sesuai Syarat Didaktis (Kebutuhan dan Kemampuan Peserta Didik) dan Kebahasaan atau syarat Konstruksi dan Desaianatau Syarat Teknis (Kegrafikan). Pada aspek indentitas hasil validasi RPP memperoleh nilai 85 dengan kategori sangat valid tidak perlu revisi. Aspek Materi atau Isi sesuai Syarat Didaktis (Kebutuhan dan Kemampuan Peserta Didik) hasil validasi materi memperoleh nilai validasi 84 dengan kategori sangat valid, dapat digunakan tanpa revisi. Adapun aspek Desaianatau Syarat Teknis (Kegrafikan) memperoleh nilai validasi 85 dengan kategori valid dengan revisi serta aspek bahasaatau syarat Konstruksihasil validasi bahasa memperoleh nilai validasi 83 dengan kategori valid dengan revisi.

Dengan demikian rata-rata skor keseluruhan pada validasi LKPD adalah yaitu 84,3 termasuk pada kategori sangat valid, dapat digunakan tanpa revisi. Hal ini menunjukkan bahwa LKPD yang dikembangkan sudah valid. Dengan demikian berarti 
LKPD yang dikembangkan sudah baik dan dapat digunakan sebagai sumber belajar bagi peserta didik dalam pengembangan LKPD berbasis pendekatan discovery learning pada pembelajaran tematik terpadu kelas V sekolah dasar.

\section{1) Uji Praktikalitas}

Data hasil uji praktisi merupakan penyajian data hasil responden terhadap produk LKPD. Responden yang dimaksud adalah 1 orang guru kelus, 5 orang peserta didik. Data ini berguna untuk melihat tingkat kepraktisan dan ketertarikan terhadap produk. Berikut data hasil uji praktisi angket responden:

a) Data Hasil Angket Respon Guru

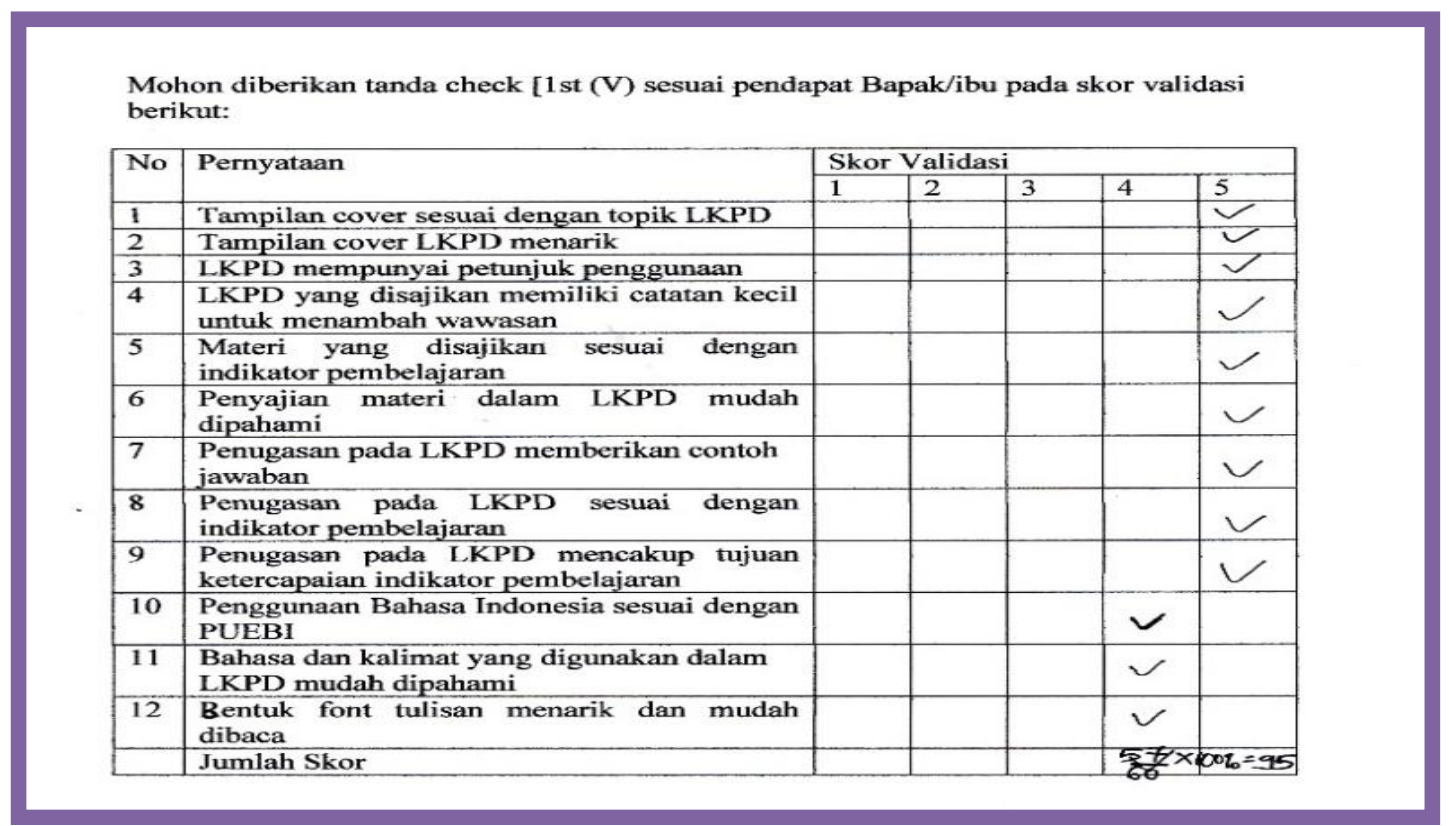

Gambar 1. Data Hasil Angket Respon Guru

b) Data Hasil Respon Peserta Didik Terhadap LKPD

Tabel 5. Data Hasil Respon Peserta Didik Terhadap LKPD

Pembelajaran I

\begin{tabular}{clccc}
\hline \multirow{2}{*}{ No } & \multicolumn{1}{c}{ Nama } & & Nilai & Hasil \\
& & BI & IPA & Nilai \\
\cline { 2 - 5 } & & 10 & 10 & 10.0 \\
\hline 1 & Aliyya Nofid & 9.2 & 10 & 9.6 \\
\hline 2 & Fahada Qisti Nadien & 10 & 8.8 & 9.4 \\
\hline 3 & Arifa Nur Al-Fath & 9.2 & 10 & 9.6 \\
\hline 4 & Daffa Habiburrahman & 10 & 10 & 10.0 \\
\hline 5 & Daffa Julion Jonathan & & & \\
\hline
\end{tabular}

Pembelajaran II

\begin{tabular}{clcccc}
\hline \multirow{2}{*}{ No } & \multirow{2}{*}{ Nama } & \multicolumn{3}{c}{ Nilai } & Hasil \\
& & BI & IPA & SBdP & Nilai \\
\hline & & 7.5 & 10 & 9.5 & 9.0 \\
\hline 1 & Aliyya Nofid & 7.5 & 10 & 10 & 9.2 \\
\hline 2 & Fahada Qisti Nadien & 7.5 & 9.5 & 10 & 9.0 \\
\hline 3 & Arifa Nur Al-Fath & 7.5 & 9.5 & 10 & 9.0 \\
\hline 4 & Daffa Habiburrahman & & & &
\end{tabular}


$\begin{array}{llllll}5 & \text { Daffa Julion Jonathan } & 7.5 & 10 & 10 & 9.2\end{array}$

Pembelajaran III

\begin{tabular}{cccccc}
\hline \multirow{2}{*}{ No } & \multirow{2}{*}{ Nama } & \multicolumn{3}{c}{ Nilai } & $\begin{array}{c}\text { Hasil } \\
\text { Akhir }\end{array}$ \\
\cline { 3 - 6 } & & BI & IPA & SBdP & Nilai \\
\hline 1 & Aliyya Nofid & 9.4 & 10 & 10 & 9.8 \\
\hline 2 & Fahada Qisti Nadien & 10 & 10 & 10 & 10.0 \\
\hline 3 & Arifa Nur Al-Fath & 10 & 10 & 10 & 10.0 \\
\hline 4 & Daffa Habiburrahman & 10 & 8.6 & 10 & 9.5 \\
\hline 5 & Daffa Julion Jonathan & 10 & 10 & 9.2 & 9.7 \\
\hline
\end{tabular}

\section{c) Pengolahan Data}

\section{1) Pengolahan Data Uji Validitas}

Skor yang diperoleh dari validator di jumlahkan dan dibagi dengan skor total ideal yang di dapat dari banyaknya aspek butir penilaian dikali dengan skor tertinggi yaitu nilai konversi 4. Setelah di peroleh skor validator dan skor lotal ideal, selanjutnya di masukkan kedalam rumus untuk memperoleh hasil persentasenya. Berikut penjelasan pengolahan data hasil validasi ahli :

a) Validasi Aspek Materi

Validasi aspek materi tahap 1 dari satu orang validator diperoleh hasil persentase sebagai berikut:

Validitas $=\frac{\text { Skor yang diperoleh }}{\text { skor maksimum }} \times 100 \%$

$=\frac{36}{44} \times 100 \%=0,81 \times 100 \%=81 \%$

Validasi aspek materi tahap 2 dari satu orang validator diperoleh hasil persentase sebagai berikut:

$$
\begin{aligned}
\text { Validitas } & =\frac{\text { Skor yang diperoleh }}{\text { skor maksimum }} \times 100 \% \\
& =\frac{37}{44} \times 100 \%=0,84 \times 100 \%=84 \%
\end{aligned}
$$

b) Validasi Aspek Desain

Validasi aspek desain tahap 1 dari satu orang validator diperoleh hasil persentase sebagai berikut:

$$
\begin{aligned}
\text { Validitas } & =\frac{\text { Skor yang diperoleh }}{\text { skor maksimum }} \times 100 \% \\
& =\frac{28}{52} \times 100 \%=0,53 \times 100 \%=53 \%
\end{aligned}
$$

Validasi aspek desain tahap 2 dari satu orang validator diperoleh hasil persentase sebagai berikut:

$$
\begin{aligned}
\text { Validitas } & =\frac{\text { Skor yang diperoleh }}{\text { skor maksimum }} \times 100 \% \\
& =85 \%
\end{aligned}
$$

c) Validasi Aspek Bahasa

Validasi aspek bahasa dari satu orang validator diperoleh hasil persentase sebagai berikut:

$$
\begin{aligned}
\text { Validitas } & =\frac{\text { Skor yang diperoleh }}{\text { skor maksimum }} \times 100 \% \\
& =\frac{33}{40} \times 100 \%=0,83 \times 100 \%=83 \%
\end{aligned}
$$




\section{2) Pengolahan Data Uji Praktisi}

a) Pengolahan Data Angket Respon Guru

Persentase pada hasil panyajian data uji praktikalitas di atas, diperoleh menggunakan perhitungan sebagai berikut :

Validitas $=\frac{\text { Skor yang diperoleh }}{\text { skor maksimum }} \times 100 \%$

Skor yang diperoleh dari validator dibagi dengan skor total ideal yang di dapat dari banyaknya aspek butir penilaian dikali dengan skor tertinggi yaitu nilai konversi 4. Setelah di peroleh skor validator dan skor lotal ideal, selanjutnya di masukkan kedalam rumus untuk memperoleh hasil persentasenya. Adapun hasilnya sebagai berikut :

$$
\begin{aligned}
\text { Validitas } & =\frac{\text { Skor yang diperoleh }}{\text { skor maksimum }} \times 100 \% \\
& =\frac{57}{60} \times 100 \%=0,95 \times 100 \%=95 \%
\end{aligned}
$$

b) Pengolahan Data LKPD Respon Siswa

Pengolahan data untuk LKPD yang diberikan siswa adalah dengan cara memberikan penilaian pada setiap mata pelajaran dalam setiap pembelajaran yang ada. Kemudian nilai akhirnya didapatkan dengan cara menambahkan jumlah nilai setiap mata pelajaran pada setiap bembelajaran yang ada dibagi dengan jumlah mata pelajaran yang ada.

Pengembangan LKPD berbasis pendekatan discovery learning pada pembelajaran tematik terpadu kelas $\mathrm{V}$ sekolah dasar menggunakan model pengembangan 4-D telah berhasil dilaksanakan dengan baik.Paparan pembahasan mengenai hasil penelitian pengembangan yang telah dilakukan, akan diuraikan lebih lanjut. Untuk lebih jelasnya, dapat diuraikan sebagai berikut:

\section{Tahap Pendefinisian (Define)}

Tahap penfinisian (define) yaitu tahap menganalisis hal-hal yang dibutuhkan pada penelitian pengembangan. Adapun analisis yang dilakukan yaitu analisis awal (analisis kebutuhan), analisis siswa (peserta didik), analisis kurikulum didalamnya membahasa analisis tugas, analisis konsep dan analisis perumusan tujuan pembelajaran.

\section{a. Analisis Awal (Analisis Kebutuhan)}

Analisis kebutuhan merupakan analisis yang dibutuhkan untuk melakukan penelitian pengembangan. Adapun analisis kebutuhan dilakukan pada penelitian ini adalah analisis pada LKPD yang digunakan pendidik dan peserta didik dalam pembelajaran. Melalui analisis LKPD terlihat bahwa LKPD perlu dikembangkan. Berdasarkan hasil analisis yang dilakukan, diperolah bahwa guru hanya memberikan arahan untuk mengerjakan LKPD yang berada pada buku siswa tanpa membuat LKPD baru untuk menarik motivasi siswa dalam belajar.

Dengan demikian, dapat dikatakan bahwa LKPD yang digunakan dalam pembelajaran belum dikembangkan secara efektif dan perlu revisi serta pengembangan lebih lanjut. Sajian materi pada LKPD perlu diberikan panduan berbagai tugas terkait memaksimalkan pemahaman peserta didik terhadap materi dan pertanyaan. Kemudian tampilan LKPD perlu didesain dengan cara yang berbeda agar lebih menarik sehingga peserta didik lebih termotivasi dalam mengerjakan LKPD.

Berdasarkan analisis awal (analisis kebutuhan) yang dilakukan, maka perlu dilakukan pengembangan LKPD berbasis pendekatan discovery learning pada pembelajaran tematik terpadu untuk membantu pendidik dalam membimbing dan memfasilitasi peserta didik untuk lebih aktif dan terampil dalam mengerjakan LKPD tematik terpadu.

Berdasarkan analisis LKPD yang peneliti lakukan pada LKPD yang digunakan pendidik, peneliti menemukan bahwa LKPD yang digunakan belum sepenuhnya 
memuat ketercapaian kompetensi dasar yang harus dimiliki peserta didik khususnya pada pelajaran. Oleh karena itu, peneliti mencoba mengembangkan LKPD berdasarkan indikator-indikator yang telah dikembangkan pada pembelajaran sehngga mampu mencapai tujuan kompetensi dasar dikembangkan. LKPD yang dikembangkan memperhatikan beberapa unsur yaitu Bahasa dan materi, RPP dan desain pada LKPD temati terpadu. Dengan memperhatikan desain LKPD memiliki daya tarik sehingga peserta didik lebih semangat dan antusias dalam mengerjakan LKPD tematik terpadu.

\section{b. Analisis Peserta Didik}

Analisis peserta didik merupakan telah karakteristik peserta didik yang meliputi usia, tingkat perkembangan bahasa, keterampilan membaca, dan latar belakang pengetahuan lainnya. Hal ini sesuai dengan pendapat Uno (2007:27) bahwa mengidentifikasi tingkah laku dan karakteristik peserta didik sangat perlu dilakukan untuk mengetahui kualitas perseorangan yang dapat dijadikan sebagai petunjuk dalam perencanaan pembelajaran. Analisis ini akan dijadikan kerangka acuan dasar pengembangan LKPD berbasis pendekatan discovery learning pada pembelajaran tematik terpadukelas V SD.

Berdasarkan pendapat para ahli diatas tersebut, maka disimpulkan bahwa dibutuhkan LKPD berbasis pendekatan discovery learningpada pembelajaran tematik terpadukelas V SD untuk mampu meningkatkan kemampuan peserta didikd dalam mengerjakan soal-soal dalam LKPD yang di berikan pendidik dengan menggunakan model pembelajaran berbasis pendekatan discovery learning.

\section{c. Analisis Kurikulum}

Dalam analisis kurikulum dijelaskan berupa analisis tugas, analisis konsep dan anlisis perumusan tujuan pembelajaran. Dimana tugas yang akan diberikan kepada siswa (peserta didik) dapat terlihat pada KI, KD dan tujuan pembelajaran yang disampaikan. Selanjutnya untuk analisis konsep adalah pengidentifikasian konsepkonsep yang akan disampaikan dalam pembelajaran serta penyusunan secara sistematis LKPD yang akan dikembangkan berdasarkan KI, KD dan tujuan pembelajaran.

Analisis kurikulum yang dikembangkan berupa analisis KI dan KD dari buku guru yang dikhususkan pada materi pembelajaran tematik terpadu di kelas V Semester II. Dimana khusus untuk KD nya difokusukan pada tema 9 sub tema 1. Analisis ini bertujuan untuk mengetahui cakupan materi, tujuan pembelajaran, pemilihan model yang sesuai untuk mengembangkan LKPD.

Berdasarkan paparan analisis awal (analisis kebutuhan), analisis siswa (peserta didik) dan analisis kurikulum di atas, maka LKPD yang dikembangkan diupayakan memiliki karakteristik, sebagai berikut: (1) LKPD disusun berdasarkan K13; (2) kompetensi yang dikembangkan adalah pembelajaran tematik terpadu; (3) LKPD berbasis pendekatan discovery learning pada pembelajaran tematik terpadu (4) Rencana Pelaksanaan Pembelajaran (RPP) dikembangkan dengan berbasis pendekatan discovery learning pada pembelajaran tematik terpadu (5) pemilihan teks dalam LKPD sesuai dengan karakteristik peserta didik; (6) isi materi dan tugas/latihan dalam LKPD mengembangkan wawasan intelektual dan, (7) penilaian seperti bentuk dan skor penilaian tercantum dalam setiap RPP.

\section{Tahap Perancangan (Design)}

Tahap perancangan dimulai dengan memvalidasi LKPD oleh validator. RPP, Materi dan bahasa dan desain. LKPD yang telah dikembangkan dikatakan valid apabila memenuhi kriteria tertentu. Menurut Arikunto (2005:167), "validitas adalah keadaan yang menggambarkan tingkat instrumen yang bersangkutan maupun mengukur apa yang akan diukur". Selanjutnya komponen-komponen produk tersebut harus konsisten satu sama lain (validitas konstruk).

Validasi yang dilakukan terhadap RPP, materi dan bahasa dan desain pada LKPD 
berbasis pendekatan discovery learning pada pembelajaran tematik terpadu kelas $\mathrm{V}$ sekolah dasar pada penelitian ini menekankan pada validitas isi (content validity) dan validitas konstruksi (construct validity). Validitas isi telah dinyatakan valid oleh validator karena RPP, materi dan bahasa dan desain LKPD berbasis pendekatan discovery learning yang dikembangkan telah sesuai dengan pembelajaran tematik terpadu di kelas V SD.

\section{Tahap Pengembangan (Develop)}

Tahap pengembangan meliputi validasi RPP dan LKPD, uji praktikalitas, dan uji efektifitas. Berdasarkan analisis data penilaian validasi oleh validator, maka RPP dan LKPD dengan tema benda-benda disekitar kita, sub tema benda tunggal dan campuran yang dikembangkan sangat valid. Berikut ini akan dipaparkan secara jelas uraian RPP dan LKPD yang telah dikembangkan.

Berdasarkan hasil analisis data, secara keseluruhan hasil validasi RPP dan materi, validasi LKPD berupa validasi desain serta hasil validasi bahasa dapat dijelasnkan bahwa terlihat nilai validasi untuk aspek RPP, validasi materi, validasi desain, dan validasi bahasa sesuai Syarat Didaktis (Kebutuhan dan Kemampuan Peserta Didik) dan Kebahasaan atau syarat Konstruksi dan Desaianatau Syarat Teknis (Kegrafikan). Pada aspek indentitas hasil validasi RPP memperoleh nilai 85 dengan kategori sangat valid tidak perlu revisi. Aspek Materi atau Isi sesuai Syarat Didaktis (Kebutuhan dan Kemampuan Peserta Didik) hasil validasi materi memperoleh nilai validasi 84 dengan kategori sangat valid, dapat digunakan tanpa revisi. Adapun aspek Desaianatau Syarat Teknis (Kegrafikan) memperoleh nilai validasi 85 dengan kategori valid dengan revisi serta aspek bahasaatau syarat Konstruksihasil validasi bahasa memperoleh nilai validasi 83 dengan kategori valid dengan revisi.

Dengan demikian rata-rata skor keseluruhan pada validasi LKPD adalah yaitu 84,3 termasuk pada kategori sangat valid, dapat digunakan tanpa revisi. Hal ini menunjukkan bahwa LKPD yang dikembangkan sudah valid. Dengan demikian berarti LKPD yang dikembangkan sudah baik dan dapat digunakan sebagai sumber belajar bagi peserta didik dalam pengembangan LKPD berbasis pendekatan discovery learning pada pembelajaran tematik terpadu kelas $\mathrm{V}$ sekolah dasar.

Satu hal yang perlu diingat oleh pendidik selain mengembangkan LKPD dalam rangka meningkatkan hasil belajar peserta didik, yaitu perlunya suatu reward atau penghargaan yang diberikan kepada peserta didik. Hal ini sejalan dengan yang diungkapkan Surbakti (2019) pemberian reward pada peserta didik dapat meningkatkan hasil belajar siswa. Hal ini dapat dilihat test terakhir yang diadakan yaitu mendapatkan skor yang jauh diatas KKM.

\section{Tahap Penyebaran (Disseminate)}

Penyebaran produk yang telah dilakukan hanya bersifat sosialisasi terbatas dikarenakan keterhatasan waktu dan biaya. Pada saat sosialisasi lerhadap produk LKPD berbasis pendekatan discovery learning pada tema 9 subtema 1 disampaikan kepada guru, peserta didik bahwa produk LKPD ini dijadikan sebagai teman belajar di rumah, agar mampu menambantu wawasan peserta didik. Produk LKPD tersebut telah di berikan kepada 1 orang guru, 5 orang peserta didik. Pada tahap ini sekaligus diminta responden untuk melihat tingkat kepraktisan produk LKPD.

\section{PENUTUP}

Berdasarkan hasil penelitian dan pengembangan yang telah dilakukan, maka dapat disimpulkan bahwa :

1. Penelitian pengembangan ini menghasilkan produk LKPD berbasis pendekatan discovery learning pada tema 9 subtema 1 dan mendapatkan hasil produk yang valid/layak dan praktis untuk digunakan, Produk LKPD yang dikembangkan ini 
telah memenuhi komponen sebagai bahan ajar yang baik untuk digunakan dalam proses pembelajaran karena sesuai dengan KI, KD dan kesesuaian warna, gambar, ukuran dan jenis huruf yang menarik. Selain itu sesuai dengan keadaara siswa, bahasa yang digunakan mudah dipahami, memiliki petunjuk belajar dan skor penilaian penugasan. Bentuk penugasan sederhana, namun mampu mencakup keseluruhan indikator pembclajaran.

2. . Dari hasil penilaian rata-rata skor keseluruhan pada validasi LKPD adalah yaitu 84,3 termasuk pada kategori sangat valid, dapat digunakan tanpa revisi. Hal ini menunjukkan bahwa LKPD yang dikembangkan sudah valid. Dengan demikian berarti LKPD yang dikembangkan sudah baik dan dapat digunakan sebagai sumber belajar bagi peserta didik dalam pengembangan LKPD berbasis pendekatan discovery learning pada pembelajaran tematik terpadu kelas V sekolah dasar.

\section{DAFTAR PUSTAKA}

Agustina. 2016. Pengembangan Perangkat Pembelajaran Konsep Pencemaran Lingkungan Menggunakan Model Pembelajaran Berdasarkan Masalah Untuk Sma Kelas X. Universitas Muhammadiyah Palangka Raya . Jurnal Edusains Vol.4 No. 2

Arikunto, S. 2008. Prosedur Penelitian Suatu Pendekatan Praktik. Jakarta: Rineka Karya

Sugiyono. 2016. Metode Penelitian Kuantitatif, Kualitatif dan R\&D. Bandung: Alfabeta

Subakti, Amelia Septiani. 2019. Pengaruh Pemberian Reward Terhadap Hasil Belajar Siswa Pada Pelajaran Matematika Kelas IV SD di SD Negeri 101740 Tanjung Selamat Tahun Pembelajaran 20182019. Universitas Katolik Santo Thomas. Jurnal Ilmiah AQUINAS Vol 2 No. 2

Trianto. 2019. Model Pembelajaran Terpadu Konsep, Strategi dan Implementasinya dalam Kurikulum Tingkat Satuan Pendidikan (KTSP). Jakarta : Bumi Aksara. 